\title{
The European Union as a Global Regulator? Context and Comparison ${ }^{1}$
}

\author{
Alasdair R. Young \\ Jean Monnet Center of Excellence \\ Center for European and Transatlantic Studies \\ Sam Nunn School of International Affairs \\ Georgia Institute of Technology
}

This paper has been conditionally accepted as the introduction of a special issue of the Journal of European Public Policy on the EU as a Global Regulator

The European Union's regulations affect how business is conducted and consumers and the environment protected in parts of the world far beyond its borders. Moreover, the external impact of its regulations informs understandings of the EU as a global actor. This article makes three main arguments. First, the EU's regulatory influence varies systematically across different forms of regulatory interaction: regulatory competition and different forms of regulatory cooperation. The form of regulatory interaction, therefore, is a critical intervening variable between the EU's regulatory power resources and its influence. Second, within the different forms of regulatory cooperation the EU's influence varies in line with expectations derived from the literature. But, third, the magnitude of the EU's influence seems to be considerably less in regulatory cooperation than suggested by the literature on regulatory competition; a finding that reinforces the first argument. The article also introduces the rest of the special issue.

Both in the academic literature and in the media the European Union is commonly characterized as an influential regulator well beyond its borders. This depiction is informed primarily by examples of regulatory competition in which firms or governments unilaterally adjust to or adopt EU rules. This literature has identified critical regulatory power resources -- a large market;

\footnotetext{
${ }^{1}$ This article is part of a wider project that has been funded with support from the European Commission (Jean Monnet Chair 2012-3121). It reflects the views only of the author, and the Commission cannot be held responsible for any use which may be made of the information contained herein. An earlier version of this paper was presented at the "Regulatory Power Europe? Assessing the EU's Efforts to Shape Global Rules" Jean Monnet Chair Workshop, Georgia Institute of Technology, 18-19 April 2014. I am grateful Vicki Birchfield, Chad Damro, Robert Kissack, Sandra Lavenex, Abraham Newman, Elliot Posner, Jamal Shahin, Kazuto Suzuki and two anonymous referees for their comments. I assert sole ownership of all errors and omissions.
} 
sophisticated regulatory capability; and stringent regulations -- which the EU possesses in abundance. Much of the literature examining the EU's participation in regulatory cooperation also finds evidence of influence, but different authors understand influence differently. Moreover, in contrast to the literature on regulatory competition, the regulatory cooperation literature finds little evidence of the EU influencing the regulations of other states; the 'gold standard' of regulatory influence. This observation, which is surprising given the EU's considerable regulatory power resources, has gone largely unexplained beyond individual cases.

Supported by the three empirical articles in the special issue, this article makes three main arguments. First, the EU's regulatory influence varies systematically across different forms of regulatory interaction: regulatory competition and different forms of regulatory cooperation -power-based bargaining with the ability to exclude others from the EU's market; power-based bargaining without the ability to exclude others from the EU's market; and rule-mediated negotiation. The form of regulatory interaction, therefore, is a critical intervening variable between the EU's regulatory power resources and its influence. Second, within the different forms of regulatory cooperation the EU's influence varies in line with expectations derived from the literature. But, third, the magnitude of the EU's influence seems to be considerably less in regulatory cooperation than suggested by the literature on regulatory competition; a finding that reinforces the first argument.

The special issue's three empirical articles - on regulatory cooperation in 'new generation' preferential trade agreements (Young); addressing greenhouse gas emissions from aviation (Birchfield); and the Maritime Labor Convention (Kissack) - illustrate the argument by representing the three major forms of regulatory cooperation. In addition, each article captures 
within-case variation - among partners (Young) or over time (Birchfield, Kissack) - which permits analysis of the impact of relative power on EU influence.

The two more conceptual articles by Newman and Posner and by Damro provide riffs on the central theme. Newman and Posner present a framework that draws on the same building blocks and similarly focus on forms of regulatory interaction; what they refer to the EU's external policy strategies, such as creating mutual recognition regimes or establishing first-mover advantage. Rather than take these forms of interaction as exogenous, they seek to explain variation in the form of interaction. In part informed by the contributions to the special issue, Damro presents a 'conceptual stock-taking exercise' that attempts to clarify important aspects of the Market Power Europe (MPE) framework and reflects upon ways in which the conceptualization may offer empirical and analytical contributions that improve our understanding of the EU as a global regulator and, more generally, as a power.

This article begins by establishing how pervasive the perception of the EU as an influential regulator beyond its borders is and how this view informs depictions of the EU as a global actor. It then discusses the existing literature on the EU as a global regulator, highlighting the variation in how influence is understood and the fragmentation of the literature. In doing so, it makes the case for treating influence as an ordinal variable. Drawing on the existing regulatory cooperation literature, the article develops the argument that the utility of different regulatory power resources varies across forms of regulatory interaction: competition and forms of cooperation. The article then illustrates the argument while introducing the empirical contributions. It concludes by drawing out the implications for the analysis of the EU's regulatory influence and by introducing the rest of the volume. 


\section{Regulation and the EU as a global actor}

There is a broad consensus that the EU is a regulatory 'great power' (Drezner 2007: 36; Sapir 2007: 12; Scott 2014: 87-8; Vogel 2012: 16; see also Lavanex 2014: 885). Bradford (2012: 5) claims that the EU is 'the predominant regulator of global commerce' (see also Jacoby and Meunier 2010: 306; Posner 2009: 692). In the late 2000s the Commission (2007:5) noted that the EU was 'emerging as a global rule-maker.' The impression of the EU's regulatory influence is echoed in the press, with, for example, The New York Times (19 October 2013: A1) calling the EU a 'regulatory superpower' (see also the Wall Street Journal, 23 April 2002 and 26 October 2007). That the EU's regulations have effects beyond the borders of the single market is, therefore, not in doubt.

This external impact of its regulations is central to depictions of the EU as an international actor (see also Müller et al 2014: 1103). It is a crucial component of the EU's international 'presence' (Bretherton and Vogler 2006: 27). Cooper (2012) contends that 'the main output of the Brussels machine are rules that govern trade and that set standards for consumer protection, for the environment, for competition, etc.... If the power to make rules is power, then Brussels, in a modest way, is also a power.' In addition, the EU's ability to shape international agreements to reflect its regulations is often equated with 'goal attainment' in the literature assessing the EU's 'performance' in international negotiations (Dee 2013: 49-50; Jørgensen et al 2011: 599). The EU's regulatory impact, therefore, is a crucial component of why it matters in international relations.

For others, the EU's efforts to promote its regulatory choices beyond its borders reveal what type of international actor it is. The EU's coercive promotion of its regulations has led some to label it a 'normative hegemon' (Laïdi 2007: 2-3) and even an 'empire' (Zielonka 2008). 
Alternatively, the EU's championing of multilateral environmental agreements and promotion of core labor standards is often cited as evidence of the EU being a normative power (Kelemen 2010: 338; Orbie 2011: 160). Damro (2012: 682; this volume), by contrast, contends that the EU is 'best understood as a market power Europe that exercises its power through the externalization of economic and social market-related policies and regulatory measures.' There is, therefore, despite important differences of emphasis, considerable agreement that the EU's rules have significant influence beyond its borders and that this influence shapes understandings of the EU as a global actor.

\section{Limitations of the literature: Operationalization and Fragmentation}

While there is no denying that the EU's rules matter well beyond its borders, the existing literature has two reinforcing shortcomings that blur the significance of this observation. First, different authors understand regulatory influence in different ways. That is, they effectively, if implicitly, operationalize the dependent variable differently. Second, while the literature on regulatory cooperation has recently begun to examine explicitly variation in EU influence and to consider the importance of the relevant international constellation of power and preferences, it is highly fragmented (see also Müller and Falkner 2014: 1); advancing explanations with respect to single or closely related cases.

\section{The varied operationalization of influence}

Different authors understand what constitutes regulatory influence very differently. For some the focus is the EU's impact on the behavior of firms. Firms that want to export goods to or provide services in the EU may need to change their practices to secure market access. Having done so, they may opt to comply with EU standards throughout their global operations (see 
Bradford 2012; Selin and VanDeveer 2006: 14; Vogel 2012: 280; and this is what particularly occupies the press).

For many, if not most, authors regulatory influence is equated with other states changing their rules to align them with those of the EU (Müller and Falkner 2014: 2; Selin and VanDeveer 2006: 14; see also Müller et al 2014: 1103). This is the central focus of the literature on regulatory competition; 'trading up' (Bradford 2012; Selin and VanDeveer 2006; Vogel 1995). It is also the assumption of much of the literature on the EU as a global actor mentioned above. In addition, much of the literature on international regulatory cooperation is also concerned with the question of which state's regulation is adopted as the common one when harmonization occurs (see Büthe and Mattli 2011: 9; Dobbin et al 2007: 450; Koenig-Archibugi 2010: 408; Krasner 1991; Simmons 2001). Thus getting other states to align their rules with its 'exporting' its rules -- is arguably the 'gold standard' of European regulatory influence.

Other authors also focus on state behavior, but identify influence in the EU getting the other party to make adjustments to its rules, but not adopt EU rules. In the literature this takes two principal forms. One is the promotion of international standards of which the EU approves (Müller et al 2014: 1109; Young this volume). The other form involves prompting changes that reduce the adverse effects of foreign rules on EU firms, such as by getting states to accept EU rules as equivalent in effect to their own (Bach and Newman 2007: 839; Newman and Posner this volume; Posner 2009: 674-6; 687; Young this volume). In both forms, the EU influences others' rules, but does not export its own.

Other scholars have identified the EU's influence in shaping multilateral agreements. The EU is described as 'exporting' (Kelemen 2010: 341; Newman and Posner this volume), 'externalizing' (Damro 2012: 686), and 'up-loading' (Smith 2010: 937) its rules. Some have 
found evidence of the EU successfully 'uploading' its regulations into international standard setting bodies, such as the International Labor Organization (ILO) (Kissack 2011: 657; Tortell et al 2009: 125); the United Nations Economic Commission for Europe (Porter 2011: 80); and the Basel Committee (Quaglia 2014a). Even when the EU up-loads its regulations into international standards, other states do not necessarily incorporate those standards into their national rules (Kissack 2011: 658; Quaglia 2014a: 328). Thus shaping international standards does not necessarily translate into changes in state behavior.

Other authors highlight the EU's impact on specific steps that lead to an international agreement, such as setting the agenda (Birchfield this volume; Kelemen 2010: 342-4; Newman and Posner this volume; Oberthür and Roche Kelly 2008: 36) or getting other actors to change their positions (Kelemen 2010: 344; Kissack this volume). Yet others (e.g., van Schaik 2013: 111) identify EU influence in its ability to block the adoption of rival standards. The existing literature, therefore, defines the EU's regulatory influence in a variety of ways; it is effectively operationalized differently.

The tendency in the literature is to treat these different operationalizations of influence discreatly and each in a binary fashion. The EU demonstrates the particular form of influence or (usually implicitly) does not, and other understandings are not explicitly considered. Arguably it is more appropriate to treat the different operationalizations as different values of influence that differ considerably in terms of how difficult they are to realize. It is easier to affect the behavior of firms than the policies of states. It is easier to get states to adopt international standards rather than European rules because they are more widely accepted and tend to be less demanding (Müller et al 2014: 1109). It is easier to block a rival rule than have one's own adopted as an international standard. It is easier to secure a modest change than a radical one. It is easier to 
influence an agreement than to get others to implement and enforce it. In addition, some forms of influence may be prior to others. For instance, agenda setting and/or shaping the preferences of others may enable the EU to influence an international agreement, which in turn is prior to getting states to change their policies as a result of implementing it. Failure to acknowledge such differences about what constitutes influence has muddied the analytical waters. Treating the different manifestations of impact as different values of influence (see Box 1) converts influence from a fragmented, binary variable to a single, ordinal one, which facilitates comparison among cases. This is the approach adopted in this special issue.

\section{INSERT BOX 1 ABOUT HERE}

\section{Belated and fragmented attention to variance in influence}

A common point of departure in any new field of study is establishing that the subject is worthy of study. This leads to an understandable tendency to focus on and enumerate instances of the EU's regulatory impact (see, for instance, Bradford 2012: 30; Damro 2012: 694; Kelemen and Vogel 2010: 428; Vogel 2012: 90; 170). ${ }^{2}$ No author claims that the EU influences all firms' behavior or all states' regulations all of the time. Many authors acknowledge explicitly that it does not, but those instances have only recently been included explicitly in analyses. Consequently, the existing literature is dominated by examples of the EU's influence (however understood). When inferences are drawn from this skewed set of cases, the extent of the EU's influence is exaggerated.

An emphasis on examples of the EU's regulatory influence also has the pernicious effect of inhibiting explanations of the extent and limits of that influence. Establishing how the EU

\footnotetext{
${ }^{2}$ Much of the work cited in the preceding section on the variable definition of influence also illustrates this point.
} 
causes others to change their ways requires analysis of examples of both success and failure so as to be able to identify those factors that correlate with the different outcome. Some of the recent literature on regulatory cooperation has begun to do just that (Groen et al 2012; Newman and Posner this volume; Oberthür and Rabitz 2014; Posner 2009; Qualia 2014). It is on this literature that this article draws in the next section.

Much of this literature, however, has focused on individual cases or on variation within a particular issue area (see also Müller and Falkner 2014: 1). ${ }^{3}$ Such a focus on closely related cases has methodological merit because it facilitates isolating the significance of particular variables by keeping others constant. The same approach is adopted in the empirical articles in this special issue. The disadvantage of this tight focus, however, is that it obscures the relevance of broader factors. In particular, it masks how the form of regulatory interaction refracts the EU's regulatory power resources.

\section{Regulatory interaction and the imperfect fungibility of regulatory power resources}

The global regulation literature identifies two broad forms of regulatory interaction: policy diffusion, in which convergence occurs through one state aligning its policies with another's; and regulatory cooperation, in which alignment comes about through a process of negotiation. ${ }^{4}$

Within each of these broad categories are several different forms of interaction. Because of its

\footnotetext{
${ }^{3}$ There are two partial exceptions. Both Drezner (2007) and Müller and Falkner (2014) (eds) consider a wide range of policies that fall within different forms of regulatory interaction. In neither case, however, is the focus explicitly on influence. Drezner analyzes the likelihood of regulatory coordination, with an emphasis on the degree of great power agreement. In addition, he does not explicitly consider the relevance of different contexts on the interaction among the great powers. Müller and Falkner's (2014: 6) main concern is the form of interaction and whether the EU has tended to export, import or protect its rules. There is a very limited focus on explaining the observed variation (Falkner and Müller 2014: 223-4).

${ }^{4}$ Simmons (2001: 598-9) distinguishes between 'market' and 'political' mechanisms. Bütte and Mattli (2011: 19) distinguish between 'market' and 'non-market' mechanisms. Koenig-Archibugi (2010: 408), Lazer (2006: 456) and Holzinger et al (2008: 556) draw tri-partite distinctions, but these include one cooperative mechanism and two policy diffusion mechanisms. Müller and Falkner (2014: 8) identify four mechanisms: 'bargaining' (cooperation) and three forms of diffusion.
} 
issue-specific focus, the literature on the EU's regulatory influence overlooks the differences among these avenues of influence. This is problematic, because, as the global regulation literature suggests, different regulatory power resources matter more in each.

Although policy diffusion can occur as the result of several different processes (Dobbin et al 2007: 452; Koenig-Archibugi 2010; Lazer 2006: 456), the form of regulatory diffusion that gets by far the most attention in the EU-as-a-global-regulator literature is regulatory competition. The emphasis in the EU literature is primarily on the 'race to the top'/'trading-up' (Vogel 1995; see also Bradford 2012: 30; Selin and VanDeveer 2006: 14). The logic is that foreign firms, having adapted their product or practices in order to gain access to the EU's valuable market, may lobby successfully their home governments to adopt comparable regulations in order to offset the costs of complying with competing requirements and/or to gain advantage over domestically oriented competitors (Bradford 2012: 5; Vogel 1995). Thus the size (value) of the EU's market, the stringency of its rules and (implicitly) its capacity to enforce them are the key factors affecting the EU's influence through regulatory competition. Although Vogel (1995) put considerable emphasis on the factors that condition whether trading-up occurs, there have been few explicit studies of failures of trading-up (Princen 2004; Young 2003). The resulting tendency to focus on successful cases has also fostered the impression that the EU is particularly influential and the assumption that its regulatory power resources translate relatively smoothly into influence (see, for example, Bradford 2012).

The existing literature on the EU's experience of regulatory cooperation, while also tending to accentuate the positive, is much more alive to the limits of EU influence than the literature dealing with regulatory competition. Regulatory cooperation occurs through either power-based bargaining between states outside institutional frameworks or rule-mediated 
negotiations within international organizations (Büthe and Mattli 2011: 19; Simmons 2001: 5989; see also Newman and Posner this volume). The literature on regulatory cooperation suggests that different power resources have different utilities in these different types of interaction. The tendency of the regulatory cooperation literature to focus on individual or closely related cases, however, has masked the implications of this insight.

The regulatory cooperation literature has focused on the same regulatory power resources as the regulatory competition literature: market size; rule stringency; and regulatory capacity. Because regulatory cooperation implies strategic interaction and because the EU is an international organization as well as an international actor, there is also an issue about the EU's ability to pursue a common position; to be internally cohesive (Conceição-Heldt and Meunier 2014: 969; Van Schaik 2013: 176). The existence of an EU rule, however, significantly eases the problem of cohesiveness (Quaglia 2014b; Young 2002). Regulatory cooperation authors have also been much more explicit in considering how the EU's power and preferences relate to those of other key actors.

The critical starting assumption in the literature on regulatory cooperation is that each party would prefer its own standard to be adopted as the common one, as this brings benefits without the costs of adjustment (see Büthe and Mattli 2011: 12; Drezner 2007: 32). Certainly where the EU has existing rules, which is usually the case, the EU is assumed to want regulatory cooperation to occur on its own terms (see Damro 2012: 686; Kelemen 2010: 341; Smith 2010: 937).

When regulatory cooperation takes place outside formal institutions, the form of cooperation is determined by bargaining power, not least because of the distributional implications of the choice of standard (Drezner 2007: 5; Krasner 1991: 336). Bargaining power 
reflects which party has the better alternative to negotiated agreement (BATNA), which in turn reflects the distribution of costs and benefits stemming from their interdependence (Keohane and Nye 2001: 9; Putnam 1988: 442). The distribution of costs and benefits associated with interdependence are, in turn, profoundly affected by whether the party with the more stringent standard can exclude goods or services that do not comply with that standard from its market (Lazer 2006: 460; Young and Wallace 2000: 24-5). Where exclusion is possible, the party with the more stringent rules has the superior BATNA, as foreign products or service providers are excluded from its market and its firms are protected from competition. When exclusion is not possible, the party with the more stringent regulations tends to have a worse BATNA than its negotiating partner(s). Its firms arguably face higher productions costs, and so are less competitive, and foreign products are not normally excluded from its market. Bargaining power, therefore, is fundamentally different in the two scenarios.

Given sufficient enforcement capacity, exclusion is essentially automatic with respect to stringent product standards. Although the single market's has generally had a liberalizing effect on services (Young and Peterson 2014: 141-2), there are a few areas in which the EU's rules apply explicitly to service providers based outside the EU. The most prominent examples of such 'territorial extension' (Scott 2014) are in financial services (Dür 2011; Posner 2009); data protection (Newman 2008: Princen 2004); and aviation with respect to greenhouse gas emissions (Birchfield this volume; Scott 2014). The larger the excluding party's market, the greater the incentive to secure access to the market (Bach and Newman 2007: 827; Drezner 2007: 35, 51) and thus to reach accommodation. Given the EU's large market, its generally stringent regulations and its considerable regulatory capacity, the EU's negotiating leverage is formidable in power-based bargaining when exclusion is possible. 
There is, however, a question as to how much of an adjustment cost foreign firms are willing to incur in order to secure the benefit of greater market access. It is possible that if the EU's regulations are too stringent, the costs of adjustment would outweigh the benefits of cooperation (Drezner 2007: 46-7). Thus stringent rules are a source of negotiating leverage, but only up to some tipping point. This suggests that relative preferences, reflecting the stringency of existing standards, matter even when exclusion is possible (see Young this volume).

The EU's regulatory power resources are much less potent when exclusion is not possible. The most prominent example of such negotiations are those concerning efforts to address climate change. In this context the EU's market size matters only to the extent that it is part of the problem and its participation is crucial to a solution (McCormick 2007: 158; Oberthür 2011: 677-8). Consequently, the EU has used its regulatory capacity and stringent rules for demonstration effect and to lend its positions legitimacy, rather than for bargaining leverage (Kelemen 2010: 337; Oberthur and Roche Kelly: 2008: 36).

The literature on bargaining without exclusion also highlights the importance of the EU's preferences relative to those of other actors and to the status quo. The EU is less likely to affect the outcome if it is pushing for change (is 'reformist') and is a preference outlier (Groen et al 2012: 185). Where the EU's position is 'conservative,' preferring the status quo, the EU's economic importance means others have an incentive to accommodate it in order to secure its participation and enhance the significance of the agreement (Oberthür and Rabitz 2013: 2). In addition, the EU's cohesiveness may be undermined if its negotiating position goes beyond what has already been adopted internally (Groen et al 2012: 184). Thus, for a variety of reasons, when exclusion is not possible, stringent standards and a large market do not lend negotiating leverage to nearly the same extent as they do when exclusion is possible. 
The implications for the utility of regulatory power resources are similar within formal, state-centric international standard setting bodies, where decision-making is rule mediated. The critical difference is that, although the norm in international standard setting bodies is to seek consensus, some can take decisions by voting. Because the EU's member states are individually members of international standard setting bodies, voting does give the EU greater weight than other actors. That greater weight, however, depends on the EU having a cohesive position (Quaglia 2014a: 328; Kissack this volume). When voting is possible, despite its vote advantage, the EU is rarely able on its own to block standards that it does not like, although it need not implement them. The EU's market size, therefore, matters only in the sense that a standard implemented by the world's largest market is more valuable than one that it ignores (Quaglia 2014a: 328). In some circumstances, however, the EU may be able to exploit its economic weight to influence the preferences of states within the standard setting body, as occurred with the Maritime Labor Convention (Kissack this volume).

Regulatory capacity, in terms of being able to gather and generate information and aggregate preferences is particularly important in shaping negotiations in international standard setting bodies (Büthe and Mattli 2011: 12-13; King and Narlikar 2003). Stringent rules, however, increase the likelihood that the EU will a preference outlier and thus reduce the likelihood that agreed international standards will reflect its own (Young 2014). Thus, ceteris paribus, the EU's regulatory power resources are less significant with respect to rule-mediated standard setting than they are in power-based bargaining when exclusion is possible, but somewhat more so than in power-based bargaining when it is not.

The literature on regulatory cooperation, particularly that on bargaining without the possibility of exclusion and rule-mediated negotiations, also challenges the assumption that the 
EU always seeks to export its rules. Because regulatory cooperation involves strategic interaction, the EU at times advances progressive positions that are less extreme than its own rules in an effort to increase the likelihood of agreement (Goen et al 2012: 185; Mair 2008: 21-2; Van Schaik 2013: 106-8). Such moderation has been less observed in power-based bargaining when exclusion is possible. Nonetheless, it is reasonable to expect the EU to shy away from insisting on harmonization on its terms even when exclusion is possible if the adjustment costs are sufficiently high that doing so might scupper an agreement that brings other benefits. This is certainly what seems to be happening in the EU's 'new generation' preferential trade agreements (Young this volume). Thus how the EU's preferences relate to those of others can affect not just its ability to realize its objectives, but also how ambitious those objectives are (Dee 2013: 225; Groen et al 2012); whether it even tries to export its rules.

This discussion of the literature on the EU's engagement in regulatory cooperation prompts three takeaways for the volume. First, the utility of the EU's regulatory power resources varies systematically depending on the form of regulatory cooperation: whether it is power-based bargaining with or without the possibility of exclusion or rule-mediated negotiation. This insight has been obscured by the tendency of the literature to focus on individual or closely related cases that fall within the same form of regulatory cooperation. Second, how cohesive the positions of the EU's member states are is a live consideration, in a way that it is not when dealing with policy diffusion. Third, explanations of the EU's influence look beyond the EU's resources to consider how its preferences and power relate to those of other key actors. The significance of these insights is illustrated by the empirical contributions to this volume. 


\section{Introducing the empirical contributions: Illustrating the argument}

The central argument of this article is that the utility of the EU's regulatory power resources varies systematically across the forms of regulatory cooperation. The form of regulatory cooperation, therefore, is a critical intervening variable. Each of the three empirical chapters falls within one of these forms of regulatory cooperation at any given time. The new generation preferential trade agreements (Young) represent bargaining with exclusion. The aviation emissions case (Birchfield) begins as bargaining without exclusion, but with the EU's decision to incorporate flights outside the EU within the Emissions Trading System (ETS), it becomes bargaining with the prospect of exclusion. The Maritime Labor Convention (Kissack) reflects rule-mediated negotiation. Together, therefore, the three cases permit exploration of the impact of the form of regulatory cooperation as an intervening variable.

The subcases within each of the three empirical chapters capture variation in the EU's relative regulatory resources. That is, there is within-case variation in the relative power of the EU's partners. The EU has negotiated preferential trade agreements with countries that differ both in their economic size and their regulatory capacity. In the aviation emissions case the EU's effective power resources increased as a result of creating the possibility of exclusion. In the maritime labor case the EU's effective power resources increased once it began advancing common positions from 2003. Thus, in addition to capturing within-case variation, the empirical articles also represent different ways in which the EU's relative regulatory resources can vary.

As the motivating question here is what explains the EU's ability to influence regulations beyond its borders, the presumption is that the EU is seeking change away from the status quo towards its preferences. That is, it has adopted a 'progressive' position. As the literature notes, the degree to which the EU is progressive can vary. It can be amibitious or more moderate. 
Here an ambitious objective is defined as the EU seeking to secure its ideal oucome, such as adoption of its regulatory solution. In such cases the EU is often a preference outlier. A more moderate position involves the EU adopting a position closer to the status quo than its ideal outcome. In such instances, its position is more likely to be shared or supported by other actors. The assessment of how progressive the EU's preferences are thus captures how its preferences relate both to the status quo and to those of other actors. The cases capture different levels of ambition, with it being least ambitious in the Maritime Labor Convention and most ambitious with respect to aviation emissions.

The subcases in the empirical articles also capture substantial variation in the degree of EU influence. The most demanding form of influence is found with respect to the EU's preferential trade agreements, where some parties agreed to change some of their rules to conform to international standards (Young this volume). In the Maritime Labor Convention, once the EU's member states began presenting common positions, they collectively shaped aspects of the agreement, although even then they were not universally successful and many of the important issues had been settled before they began coordinating (Kissack this volume). In addition, that the EU's member states could enforce the agreed standards caused flag-states and ship-owners to moderate their opposition so as to be able to shape the rules. In the aviation emissions case (Birchfield this volume) after the EU decided to include aviation in the ETS other key players agreed to put the issue seriously on the agenda of the International Civil Aviation Organization (ICAO). Prior to the inclusion of aviation in the ETS and prior to EU coordination on maritime labor standards, the EU effectively had no influence. The EU's degree of influence across the cases, therefore, ranges from none through agenda setting and influencing the 
positions of negotiating partners to securing commitments to adopt international standards (convergence).

The findings from the three empirical chapters (summarized in Table 1) testify to the importance of the variation in the EU's power resources across different forms of regulatory cooperation. The EU's influence is greatest with respect to power-based bargaining with exclusion; prompting some policy convergence in preferential trading agreements. It is particularly telling that the decision to include aviation in the Emissions Trading System, which transformed the power-based bargaining from without exclusion to with the possibility of exclusion coincided with a sharp increase in the EU's influence, from none discernable to getting the issue on ICAO's agenda. As predicted, the EU's influence within the rule-mediated negotiation on the Maritime Labor Convention presents an intermediate case with the EU getting its way on some provisions, but not others. This analysis strongly suggests that scholars should take the form of regulatory cooperation seriously when analyzing the EU's regulatory influence.

\section{INSERT TABLE 1 ABOUT HERE}

In addition, the variation in the EU's influence within the cases is consistent with explanations advanced in the existing literature. The EU had greater influence in PTAs with smaller partners with lower regulatory capacities than with larger partners. The EU's influence in the Maritime Labor Convention increased once its internal cohesiveness increased as the member states began coordinating their positions. The inclusion of aviation emissions on the ICAO agenda came in response to the decision to include aviation in the ETS. The impact of how the EU's preferences relate to those of others, however, could not be assessed on the basis 
of the cases. There is no within-case variation in the cases of aviation and maritime labor. In the PTA cases the EU's ambition co-varied with the power of partners; seeking more ambitious outcomes with the least powerful than the most powerful. Significantly, however, while observed variance is in line with expectations about the importance of relative power, the magnitude of influence across the board is considerably less that suggested by the common view of the EU as a global regulator. This observation is consistent with the form of regulatory interaction being a critical intervening variable.

\section{Conclusion}

This article has argued that the EU is not as influential a global regulator as many assume. There two principal reasons for this over estimation. First, is the tendency to focus on examples of influence. This tendency is fostered by different authors understand influence differently. Each of these understandings is implicitly treated as a binary variable. Moreover, authors tend to find some form of influence. Second, the EU's considerable regulatory power resources are not perfectly fungible across different forms of regulatory interaction, as is typically (if implicitly) assumed. Extrapolating from regulatory competition, where these resources are particularly potent, thus creates exaggerated expectations of the EU's influence in other forms of regulatory interaction.

This article has argued that the EU's influence varies systematically across the different forms of regulatory cooperation. The utility of the EU's regulatory power resources is greatest when cooperation takes place through bargaining when foreign products or firms can be excluded from the EU's market. It is least when bargaining occurs, but exclusion is not possible. Rule-meditated negotiation represents an intermediate case. The empirical chapters in this 
volume illustrate this argument. The EU's influence is greatest - prompting rule change - in preferential trade agreements, which have the form of power-based bargain with the prospect of exclusion. The EU's efforts to have greenhouse gas emissions from aviation addressed at the global level went nowhere when bargaining occurred without the prospect of exclusion, but the decision to include aviation in the EU's Emissions Trading System, thereby providing for exclusion, led to the issue being placed on the agenda of the International Civil Aviation Organization. In the negotiations over the Maritime Labor Convention within the International Labor Organization, the EU has some influence on the agreement once it started coordinating its position, but even then only prevailed on some issues. Thus the form of regulatory cooperation would seem to be an important intervening variable refracting how the EU's regulatory power resources translate into influence.

The empirical cases also found variation in the EU's influence within a particular form of regulator cooperation. In the case of PTAs, the EU's influence was greatest where its relative power was greatest - Central America -- and seems certain to be most limited with respect to its peer - the United States. The EU's influence on the Maritime Labor Convention increased markedly once the member states began coordinating their positions. Thus within-case variation was consistent with explanations in the existing literature. The form of regulatory cooperation, therefore, is an important intervening variable, but it is only part of the story.

The next three articles present the empirical evidence that has informed this discussion. The article by Newman and Posner highlights that the relative regulatory capacity among near peers interacts with the degree of international institutionalization to influence patterns of regulatory interaction and influence. Damro's article wraps up the special issue by developing 
the concept of Market Power Europe and considering how debates about the EU's regulatory influence inform debates about what type of international actor the EU is. 


\section{References}

Bach, D. and Newman, A. L. (2007), 'The European Regulatory State and Global Public Policy: Micro-Institutions, Macro-Influence,' Journal of European Public Policy, 14:6, 827-46.

Birchfield, V. (2015), 'Coercion with Kid Gloves: The European Union’s Role in Shaping a Global Regulatory Framework for Aaircraft Emissions,' Journal of European Public Policy,

Bradford, A. (2012), 'The Brussels Effect,' Northwestern University Law Review, 107/1, 1-68.

Bretherton, C. and Vogler, J. (2006), The European Union as a Global Actor, $2^{\text {nd }}$ edition, Routledge.

Büthe, T. and Mattli, W. (2011), The New Global Rulers: The Privatization of Regulation in the WorldEconomy (Princeton University Press).

Commission (2007), 'The External Dimension of the Single Market Review,' SEC(2007) 1519, 20 November.

Conceição-Heldt, E. da and Meunier, S. (2014), 'Speaking with a Single Voice: Internal Cohesiveness and External Effectiveness of the EU in Global Governance,' Journal of European Public Policy, 21/7, 961-79.

Cooper, R. (2012), 'Hubris and False Hopes,' Policy Review, 172, 30 March.

Damro, C. (2012), 'Market Power Europe,' Journal of European Public Policy, 19/5, 682-99.

Damro, C. (2015), 'Market Power Europe: Clarifications and Contributions.' Journal of European Public Policy.

Dee, M. (2013), 'Finding Its Place in the World: Leadership, Power and the European Union,' PhD Thesis, University of Glasgow. 
Dobbin, F., Simmons, B. and Garret, G. (2007), 'The Global Diffusion of Public Policies: Social Construction, Coercion, Competition or Learning?' Annual Review of Sociology, 33, 44972.

Drezner, D. W. (2007), All Politics is Global: Explaining International Regulatory Regimes, Princeton University Press.

Dür, A. (2011), 'Fortress Europe or Open Door Europe? The External Impact of the EU's Single Market in Financial Services,' Journal of European Public Policy. 18/5, 619-35.

Groen, L., Niemann, A. and Oberthür, S. (2012). 'The EU as a Global Leader? The Copenhagen and Cancun UN Climate Change Negotiations', Journal of Contemporary European Research, 8/2, 173-191.

Holzinger, K., Knill, C. and Sommerer, T. (2008), 'Environmental Policy Convergence: The Impact of International Harmonization, Transnational Communication and Regulatory Competition,' International Organization, 62 (fall), 553-87.

Jørgensen, K. E., Oberthür, S. and Shahin, J. (2011), 'Introduction: Assessing the EU’s Performance in International Institutions - Conceptual Framework and Core Findings,' Journal of European Integration, 33/6, 599-620.

Kelemen, D. (2010), 'Globalizing European Union Environmental Policy,' Journal of European Public Policy, 17/3, 335-349.

Kelemen, R. D. and Vogel, D. (2010), 'Trading Places: The Role of the United States and the European Union in International Environmental Politics,' Comparative Political Studies, 43/4, 427-56.

Keohane, R. O. and Nye, J.S. (2001), Power and Interdependence, 3rd ed, Longman. 
King, D. and Narlikar, A. (2003), 'The New Risk Regulators? International Organisations and Globalisation,' The Political Quarterly, 74/3, 337-48.

Kissack, R. (2011), 'The Performance of the European Union in the International Labour Organization,' Journal of European Integration, 33:6, 651-665.

Kissack, R. (2015), ;The 4th Pillar of Global Maritime Regulation: EU Influence over the Drafting of the Maritime Labour Convention,'Journal of European Public Policy.

Koenig-Archibugi, M. (2010), 'Global Regulation,' in R. Baldwin, M. Cave, D. Lodge (eds), The Oxford Handbook of Regulation (Oxford: Oxford University Press): 406-33.

Krasner, S. D. (1991), 'Global Communications and National Power: Life on the Pareto Frontier,' World Politics, 43/3, April, 336-66.

Jacoby, W. and Meunier, S. (2010), 'Europe and the Management of Globalization,' Journal of European Public Policy, 17/3, 299-317.

Laïdi, Z. (2007), 'The Unintended Consequences of European Power,' Les Cahiers européene de Sciences Po, nº5 (Paris: Centre d'études européenes at Sciences Po).

Lavenex, S. (2014), 'The Power of Functionalist Extension: How EU Rules Travel,' Journal of European Public Policy, 21/6, 885-903.

Lazer, D. (2006), 'Global and Domestic Governance: Modes of Interdependence in Regulatory Policymaking,' European Law Journal, 12/4, 455-68.

Mair, M. L. (2008), The regulatory state goes global: EU participation in international food standard-setting by the Codex Alimentarius Commission,' paper to the GARNET conference on "The European Union in International Affairs", Institute for European Studies, Vrije Universiteit Brussel, April 24-26.

McCormick, J. (2007), The European Superpower (Basingstoke: Palgrave MacMillan). 
Müller, P. and Falkner, G. (2014), 'The EU as a policy exporter? The conceptual framework,' in G. Falkner and P. Müller (eds.), EU Policies in a Global Perspective: Shaping or Taking International Regimes? London: Routledge, 1-19.

Müller, P., Kudrna, Z. and Falkner, G. (2014), 'EU-Global Interactions: Policy Export, Import, Promotion and Protection,' Journal of European Public Policy, 21/8, 1102-19.

Newman, A. L. (2008), Protectors of Privacy: Regulating Personal Data in the Global Economy, Cornell University Press.

Newman, A. L. and Posner, E. (2015), 'Putting the EU in Its Place: Influence Strategies and the Global Regulatory Context,' Journal of European Public Policy

Oberthür S. (2011), ‘The European Union’s Performance in the International Climate Change Regime,' Journal of European Integration, 33/6, 667-682

Oberthür, S. and Rabitz, F. (2014), 'On the EU's Performance and Leadership in Global Environmental Governance: The Case of the Nagoya Protocol,' Journal of European Public Policy, 21/1, 39-57.

Oberthür, S. and Roche Kelly, C. (2008) 'EU Leadership in International Climate Policy: Achievements and Challenges' The International Spectator 43(3), 35-50

Orbie, J. (2011), 'Promoting Labour Standards through Trade: Normative Power or Regulatory State Europe,' in R. G. Whitman (ed.), Normative Power Europe: Empirical and Theoretical Perspectives, PalgraveMacmillan, 160-83.

Porter, T. (2011), 'Transnational Policy Paradigm Change and Conflict in the Harmonization of Vehicle Safety and Accounting Standards,' in G. Skogstad (ed.), Policy Paradigms: Transnationalism and Domestic Politics, University of Toronto Press, 64-90. 
Posner, E. (2009), 'Making Rules for Global Finance: Transatlantic Regulatory Cooperation at the Turn of the Millennium,' International Organization, 63/4, 665-99.

Princen, S. (2004), 'Trading Up in the Transatlantic Relationship,' Journal of Public Policy, 24/1, 127-44.

Putnam, R. D. (1988), 'Diplomacy and Domestic Politics: The Logic of Two-Level Games,' International Organization, 42/3.

Quaglia, L. (2014a), 'The Sources of European Union Influence in International Financial Regulatory Fora,' Journal of European Public Policy, 21/3, 327-45.

Quaglia, L. (2014b), 'The European Union, the USA and International Standard Setting by Regulatory Fora in Finance,' New Political Economy, 19/3, 427-44.

Sapir, A. (2007), 'Europe and the Global Economy,' in A. Sapir (ed), Fragmented Power: Europe and the Global Economy (Brussels: Bruegel), 1-20.

Scott, J. (2014). 'Extraterritoriality and Territorial Extension in EU Law,' American Journal of Comparative Law, 62/1, 87-125.

Selin, H. and VanDeveer, S. D. (2006), 'Raising Global Standards: Hazardous Substances and EWaste Management in the European Union,' Environment, 48/10, 6-17.

Simmons, B. A. (2001), 'The International Politics of Harmonization: The Case of Capital Market Regulation,' International Organization, 55/3, 589-620.

Smith, M. P. (2010), 'Single Market, Global Competition: Regulating the European Economy in a Global Economy,' Journal of European Public Policy, 17/7, 936-53.

Tortell, L., Delarue, R. and Kenner, J. (2009), 'The EU and the ILO Maritime Labour Convention,' in J. Orbie and L. Tortell (eds), The European Union and the Social Dimension of Globalization: How the EU influences the World, Routlege: 113-30. 
van Schaik, L. G. (2013), EU Effectiveness and Unity in Multilateral Negotiations: More than the Sum of Its Parts? Palgrave Macmillan.

Vogel, D. (1995), Trading Up: Consumer and Environmental Regulation in a Global Economy, Harvard University Press.

Vogel, D. (2012), The Politics of Precaution: Regulating Health, Safety, and Environmental Risks in Europe and the United States, Princeton University Press.

Young, A. R. (2002), Extending European Cooperation: The European Union and the 'New' International Trade Agenda, Manchester University Press.

Young, A. R. (2003), 'Political Transfer and "Trading Up": Transatlantic Trade in Genetically Modified Food and US Politics,' World Politics, 55/4, 457-84.

Young, A. R. (2014), 'Europe as a Global Regulator? The Limits of EU Influence in International Food Safety Standards,' Journal of European Public Policy,

Young, A. R. (2015), 'Liberalizing Trade, Not Exporting Rules: The Limits to Regulatory Coordination in the EU's “New Generation:” Preferential Trade Agreements,' Journal of European Public Policy

Young, A. R. and Peterson, J. (2014), Parochial Global Europe: $21^{\text {st }}$ Century Trade Politics, Oxford University Press.

Young, A. R. and Wallace (2000), Regulatory Politics in the Enlarging European Union: Weighing Civic and Producer Interests, Manchester University Press.

Zielonka, J. (2008), ‘Europe as a Global Actor: Empire by Example?’ International Affairs, 84/3, 471-84. 
Box 1 Different understandings of "influence"

\begin{tabular}{|c|} 
Getting states change to their policies \\
to harmonize with EU rules \\
to align with international standards \\
to mitigate rule clashes \\
Chaping multilateral agreements/international standards after its own rules \\
Setting the agenda in multilateral negotiations \\
Foreign firms' changing their global practices in line with EU requirements \\
Firms modifying their goods or services to sell to the EU
\end{tabular}


Table 1 Variation in key variables across cases

\begin{tabular}{|c|c|c|c|c|c|}
\hline Case & Subcases & Form of interaction & $\begin{array}{l}\text { Relative power } \\
\text { resouces }\end{array}$ & Relative preferences & Degree of influence \\
\hline \multirow{5}{*}{ 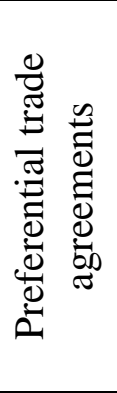 } & $\begin{array}{l}\text { Central } \\
\text { America }\end{array}$ & Power based with exclusion & Very strong & Somewhat ambitious & Weak convergence \\
\hline & Singapore & Power based with exclusion & Very strong & Somewhat ambitious & Weak convergence \\
\hline & Korea & Power based with exclusion & Strong & Somewhat ambitious & Limited convergence \\
\hline & Canada & Power based with exclusion & Strong & Moderate & $\begin{array}{l}\text { Very limited rule } \\
\text { change }\end{array}$ \\
\hline & US & Power based with exclusion & Modest & Moderate & $\begin{array}{l}\text { Convergence not } \\
\text { sought }\end{array}$ \\
\hline \multirow{2}{*}{ 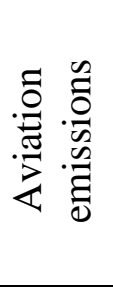 } & $\begin{array}{l}\text { Before } \\
\text { inclusion in } \\
\text { ETS }\end{array}$ & Power based without exclusion & Very weak & Ambitious & None \\
\hline & $\begin{array}{l}\text { After } \\
\text { inclusion in } \\
\text { ETS }\end{array}$ & Power based with exclusion & Modest & Ambitious & Put issue on agenda \\
\hline \multirow{2}{*}{ 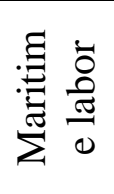 } & $\begin{array}{l}\text { Before EU } \\
\text { coordination }\end{array}$ & Rule-mediated & None & Divided & None \\
\hline & $\begin{array}{l}\text { After EU } \\
\text { coordination }\end{array}$ & Rule-mediated & Modest & Moderate & $\begin{array}{l}\text { Limited on } \\
\text { international agreement }\end{array}$ \\
\hline
\end{tabular}

